\title{
A unique population of effector memory lymphocytes identified by CD I46 having a distinct immunophenotypic and genomic profile
} Mohamed F Elshal1,6, Sameena S Khan², Nalini Raghavachari², Yoshiyuki Takahashi' ${ }^{3}$, Jennifer Barb ${ }^{4}$, James J Bailey ${ }^{4}$, Peter J Munson ${ }^{4}$, Michael A Solomon 2,5, Robert L Danner ${ }^{2}$ and J Philip McCoy Jr*1,3

\author{
Address: ${ }^{1}$ Flow Cytometry Core Facility, National Heart, Lung, and Blood Institute, National Institutes of Health. Bethesda, MD, USA, ${ }^{2}$ Functiona \\ Genomics and Proteomics Facility, Critical Care Medicine Department, Clinical Center, National Institutes of Health, Bethesda, MD, USA, \\ ${ }^{3}$ Hematology Branch, National Heart, Lung, and Blood Institute, National Institutes of Health. Bethesda, MD, USA, ${ }^{4}$ Mathematical \& Statistical \\ Computing Laboratory, Center for Information Technology, USA, ${ }^{5}$ Cardiovascular Branch, National Heart, Lung, and Blood Institute, National \\ Institutes of Health, Bethesda, MD, USA and ${ }^{6}$ Molecular Biology Department, Genetic Engineering and Biotechnology Institute, Minoufiya \\ University, Minoufiya, Egypt \\ Email: Mohamed F Elshal - melshal2002@yahoo.com; Sameena S Khan - sarwaree@earthlink.net; \\ Nalini Raghavachari - nraghavachari@mail.nih.gov; Yoshiyuki Takahashi - ytakaha@med.nagoya-u.ac.jp; Jennifer Barb - barbj@mail.nih.gov; \\ James J Bailey - baileyj@mail.nih.gov; Peter J Munson - munson@mail.nih.gov; Michael A Solomon - msolomon@mail.nih.gov; \\ Robert L Danner - dannerr@mail.nih.gov; J Philip McCoy* - mccoyjp@mail.nih.gov \\ * Corresponding author
}

Published: 13 November 2007

BMC Immunology 2007, 8:29 doi:10.1186/147|-2172-8-29
Received: 30 April 2007

Accepted: 13 November 2007

This article is available from: http://www.biomedcentral.com/I47I-2I72/8/29

(C) 2007 Elshal et al; licensee BioMed Central Ltd.

This is an Open Access article distributed under the terms of the Creative Commons Attribution License (http://creativecommons.org/licenses/by/2.0), which permits unrestricted use, distribution, and reproduction in any medium, provided the original work is properly cited.

\begin{abstract}
Background: CDI46 is a well described homotypic adhesion molecule found on endothelial cells and a limited number of other cell types. In cells from the peripheral circulation, CDI46 has also been reported to be on activated lymphocytes in vitro and in vivo. The function associated with CDI46 expression on lymphoid cells is unknown and very little information is available concerning the nature of CDI46+ lymphocytes. In the current study, lymphocytes from healthy donors were characterized based upon the presence or absence of CDI46 expression.

Results: CDI46 was expressed on a low percentage of circulating T lymphocytes, B lymphocytes, and NK cells in healthy individuals. CDI46 expression can be induced and upregulated in vitro on both B cells and T cells, but does not correlate with the expression of other markers of T cell activation. CDI46 positive $T$ cells do not represent clonal expansions as determined with the use of anti $V \beta$ reagents. Data suggest that CDI46 positive cells have enhanced adherence to endothelial monolayers in vitro. Gene profiling and immunophenotyping studies between CDI46+ and CDI46- T cells revealed several striking genotypic distinctions such as the upregulation of IL-8 and phenotypic differences including the paucity of CCR7 and CD45RA among CDI46 positive T cells, consistent with effector memory function. A number of genes involved in cell adhesion, signal transduction, and cell communication are dramatically upregulated in CDI46+ T cells compared to CDI46- T cells.
\end{abstract}

Conclusion: CDI46 appears to identify small, unique populations of $\mathrm{T}$ as well as B lymphocytes in the circulation. The $T$ cells have immunophenotypic characteristics of effector memory lymphocytes. The characteristics of these CDI46+ lymphocytes in the circulation, together with the known functions in cell adhesion of CDI46 on endothelial cells, suggests that these lymphocytes may represent a small subpopulation of cells primed to adhere to the endothelium and possibly extravasate to sites of inflammation. 


\section{Background}

CD146, a well described marker of endothelial cells, is a cell surface adhesion molecule involved in homotypic and heterotypic cell interactions $([1,2]$, reviewed by Shih [3]). On endothelial cells, it is located primarily, but not exclusively, at the endothelial junction [4]. Brief reports have also indicated the presence of CD146 on lymphocytes [5-7] and only a single report describes the presence of CD146 on peripheral blood lymphocytes [7]. While widely studied on endothelial cells, very little is known about the presence of CD146 on peripheral blood lymphocytes. Pickl and colleagues reported that CD146 expression could be induced on T cells by mitogen activation in vitro, but failed to detect circulating CD146+ T lymphocytes in healthy individuals[5]. Seftalioglu and Karakoc [6] demonstrated membrane staining of immature thymocytes, macrophages, and epithelial cells using light and electron microscopy in freshly isolated, normal thymic tissue from children, and concluded that CD146 might be a pan-antigen essential for the maintenance of thymic architecture and function. Their observation of the selective expression of CD146 on contact areas of epithelial cells and immature thymocytes led them to conclude that CD146 may play a role in signaling interactions between these two cell types.

In a recent letter, our group reported, for the first time, that a small percentage of lymphocytes freshly isolated from peripheral blood of healthy individuals express cell surface CD146 [7]. These data reveal a small, but consistently demonstrable, subpopulation of lymphocytes which are either genetically pre-programmed to express this antigen, or are activated in vivo in a manner that results in this expression. Why such a population would exist in healthy individuals is currently unknown and the subject of current investigation.

CD146 is considered a member of the immunoglobulin gene superfamily and has been reported to show structural sequence similarities with a subgroup of adhesion molecules including the activated lymphocyte cell adhesion molecule CD166 (ALCAM) [3]. In endothelial cells, a number of functional roles have been postulated for CD146 in addition to its role as a cell adhesion molecule. Using cultured endothelial cells (HUVECs), Anfosso et al demonstrated an outside-in signaling pathway linked to CD146 engagement [8]. In this pathway, activation results in the tyrosine phosphorylation of a complicated pattern of proteins, including paxillin and p125 $5^{\mathrm{FAK}}$. Engagement of CD146 in endothelial cells recruits p59fyn to the vicinity of CD146, as well as triggering a store-dependent $\mathrm{Ca}^{2+}$ influx. Solvey and colleagues [1] found that CD146 binding led to a change in cellular permeability, actin distribution, and redistribution of NF- $\mathrm{KB}$ p50 to the nucleus.
The finding of CD146, an antigen widely accepted as an endothelial adhesion molecule, on peripheral blood lymphocytes, has yet to be explained. Furthermore, there has been no previous effort to characterize the nature of CD146+ T cells in the peripheral circulation. To this end, the current study was undertaken to understand the nature of CD146+ T cells through phenotypic and genotypic profiling of these cells.

\section{Results \\ Identification of CDI46 Positive Lymphocytes}

Specimens of fresh peripheral blood from healthy individuals were stained with the monoclonal antibodies listed in the methods section and analyzed by flow cytometry. CD45/CD146 dual positive cells were consistently identified in peripheral blood samples from healthy individuals, and these were identified in lymphocyte subsets as illustrated in Figure 1. In most peripheral blood samples, the CD45+CD146+ cells represented 1\% or less of the mononuclear cells. Using a light scatter gate for lymphoid cells and viability gating, approximately $2 \%$ of the CD3 positive T cells were CD146 positive [\%dual CD3+ CD $146+/ \% C D 3+](2.09 \%$ [mean] $\pm 0.84 \%$ [SD], $\mathrm{n}=10)$. Among the CD3, CD146 positive lymphocytes, both CD4 and CD8 subsets were present. In most, but not all, individuals the proportion of CD3+CD4+ CD146+ cells was similar to $\mathrm{D} 3+\mathrm{CD} 8+\mathrm{CD} 146+$ (Figure 2). The percentage of $\mathrm{CD} 3+\mathrm{CD} 4+$ cells expressing CD146 [i.e. \%triple $\mathrm{CD} 3+\mathrm{CD} 4+\mathrm{CD} 146+/ \%$ dual CD3+CD4+] was $2.08 \% \pm$ $0.73 \%(\mathrm{n}=10)$ and the percentage of CD3+CD8+ cells expressing CD146 [i.e. \%triple CD3+CD8+ CD146+/ $\%$ dual $\mathrm{CD} 3+\mathrm{CD} 8+]$ was $2.50 \% \pm 2.47 \%$. The rather wide standard deviation on the latter was largely the result of a single patient who demonstrated $9.45 \%$ of CD8 cells expressing CD146. Exclusion of this high value yielded $1.80 \% \pm 0.94 \%(n=9)$ of the CD3+CD8+ cells expressing CD146.

The CD3, CD146 dual positive cells also expressed additional $\mathrm{T}$ cell markers CD2, CD5 and CD7, (data not shown) confirming that these cells were $\mathrm{T}$ lymphocytes rather than another cell type aberrantly expressing CD3. The use of pulse width measurements eliminated the possibility that these cells were doublets of CECs and T cells $[9]$, and the use of a viability stain (7-AAD), as well as isotype controls, excluded the possibility that this staining was due to nonspecific binding of the monoclonal antibodies. The expected immunophenotype of CECs, CD45CD3-CD146+ [10], represented an average of $0.047 \%$ of the nonerythroid peripheral blood cells (range $0.005 \%$ to $0.142 \%$ ) in the donors studied.

Soluble CD146 (sCD146) has previously been demonstrated in culture supernatants of endothelial cells as well as in the plasma of patients with chronic renal failure. To 

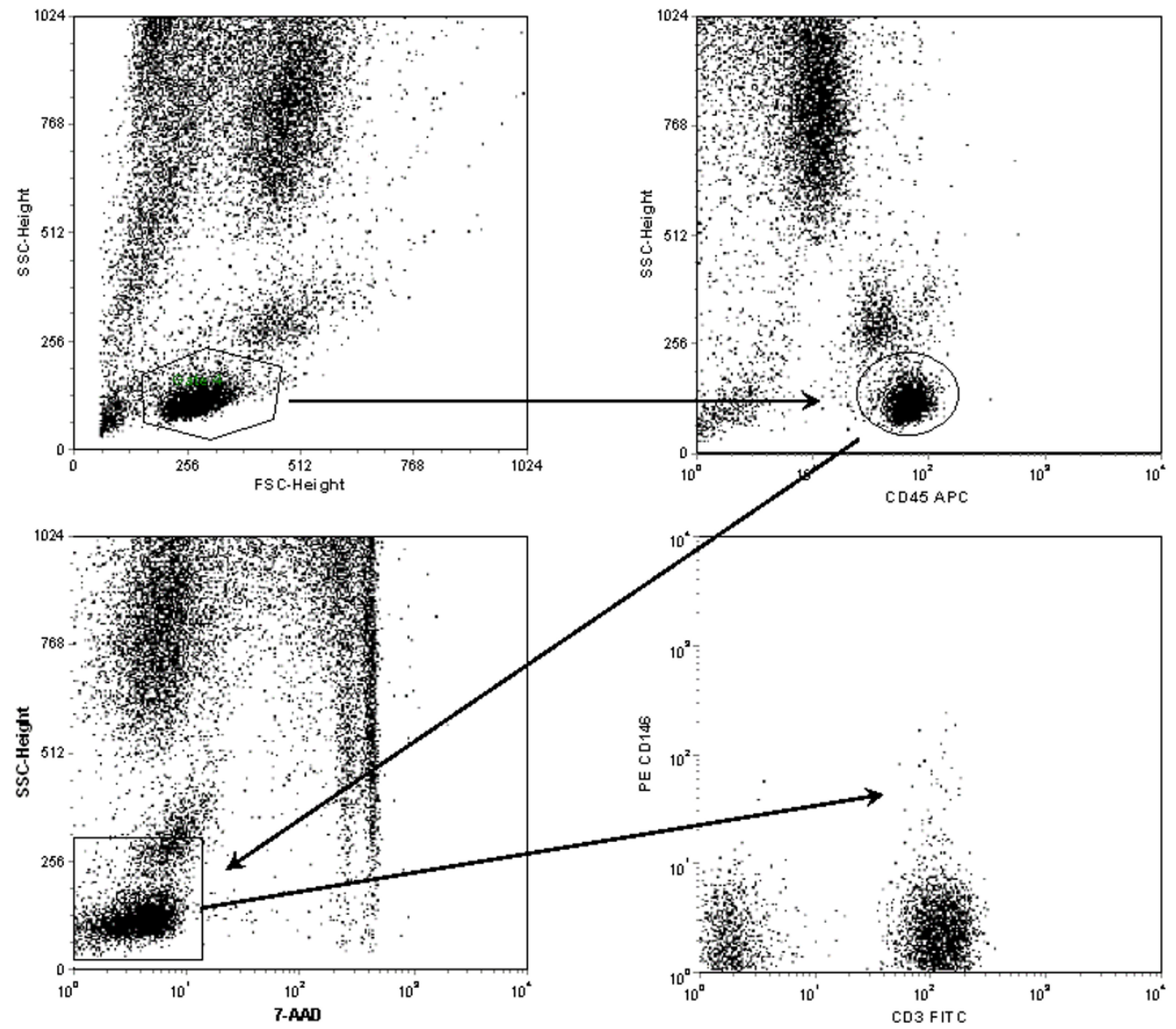

\section{Figure I}

Example of the gating strategy used to identify CDI46 positive T cells. Gates were set around lymphocytes, as defined by forward and side light scatter (upper left), CD45 bright-positive cells (upper right), and live cells determined as 7AAD-negative (lower left). All three gates were applied to the lower right dot plot displaying CD3 and CDI46.

investigate whether the CD146 present on cells in fresh peripheral blood was due to binding of soluble CD146 to these cells, peripheral blood mononuclear cells, as well as whole peripheral blood, were washed with PBS twice prior to staining as described above. No change in either the percentage of $\mathrm{T}$ cells positive for CD146 or in the intensity of CD146 staining was observed. While these data suggest that the CD146 detected on lymphocytes was intrinsic rather than extrinsic due to binding of soluble CD146, further evidence regarding the origin of lymphocytic CD146 was obtained by the in vitro activation experiments described later.

Other lymphocyte subsets, B cells and NK cells were examined for the presence of CD146. Since these cell types each comprise a far lower percentage of the lymphocytes in normal peripheral blood, larger numbers of cells (greater than $4 \times 10^{5}$ ) were collected per list mode file for analysis. CD45+, CD19+, CD146+, 7AAD- cells represented 0.74\% of CD45+, CD19+, 7AAD- B cells [i.e. \%CD45+, CD19+ CD $146+/ \% C D 45+C D 19+](0.74 \% \pm 0.86 \%, n=10)$. NK cells were identified as CD45+, CD3-, CD16+, and CD56+. In fresh peripheral blood, an extremely low percentage $(0.11 \% \pm 0.13 \%, \mathrm{n}=10)$ of the $\mathrm{NK}$ cells were determined to be CD146+ [i.e. \% CD3CD16+CD56+CD146+/\%CD3-CD16+CD56+]. These lymphocyte immunophenotyping data are summarized in Figure 2.

\section{Lack of coexpression of activation markers and leukocyte adhesion marker}

Studies were undertaken to determine if the expression of CD146 coincided with the expression of other welldefined activation markers of lymphocytes. Multicolor 


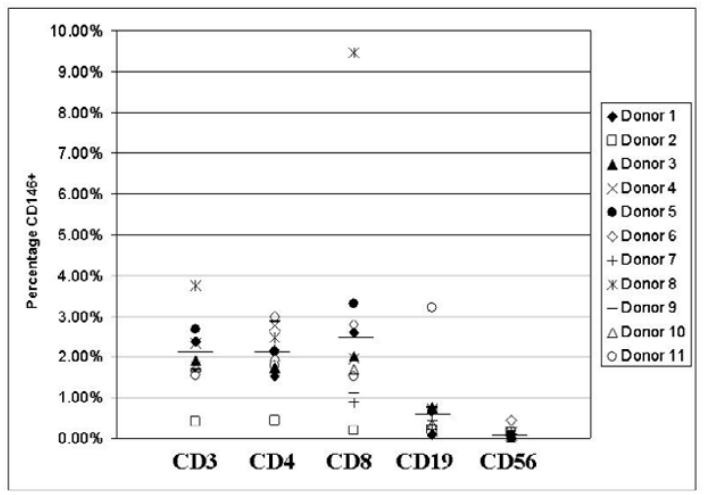

\section{Figure 2}

Expression of CDI46 by various lymphocyte subsets in the peripheral blood of healthy volunteers. Bars indicate means for each subset. All cells were gated as described for Figure I, with the addition of CD3 positive gating for CD4 and CD8, and CD3 negative gating for CD56.

flow cytometry was used to examine coexpression of CD146 with CD25, CD69, CD38, and HLA-DR on CD3 positive cells in fresh peripheral blood. Representative histograms of some of these experiments are given in Figure 3. These data indicate that CD146+CD3+ cells are largely distinct, but not entirely unique, compared to other $\mathrm{T}$ cell subsets identified by different markers of activation.

The CD3, CD146 dual positive cells were further characterized by examination of additional markers of interest. This population of cells was found to be alpha/beta positive, gamma/delta negative, and predominantly positive for expression of CD28 (Figure 4). Since there is substantial homology between CD146 and CD166 [3], (the activated leukocyte cell adhesion molecule) CD3, positive cells were examined for the coexpression of these molecules. Very few cells demonstrated coexpression of these two molecules, suggesting that these two adhesion molecules identified substantially different $\mathrm{T}$ cell subsets.

\section{TCR V $\beta$ Analysis}

The CD3, CD146 dual positive cells were TCR $\alpha \beta$ positive and TCR $\gamma \delta$ negative. To ascertain whether CD3+CD146+ cells represented clonal populations of $\mathrm{T}$ lymphocytes, a panel of antibodies to various TCR $v \beta$ regions were used to stain both freshly isolated, and mitogen-stimulated, peripheral blood mononuclear cells from healthy individuals. The data obtained from both fresh and stimulated blood indicated that CD3+CD146+ T cells were polyclo- nal, with a number of different TCR v $\beta$ regions expressed, but none exclusively or even predominantly. Thus the CD146 positive T cells did not represent a clonal expansion.

Lack of coexpression of primitive markers of lymphocytes There was a virtual absence of CD34 and CD133 on CD45+ CD146+ lymphocytes. In a sampling of 5 healthy individuals, there was an average of $0.01 \%$ of the CD45+CD146+ cells expessing CD34, and $0.016 \%$ expressing CD133.

Lack of coexpression of endothelial associated markers CD3+ T cells staining for CD146 were negative for the expression of the endothelial markers CD51/61 and von Willebrand factor. The CD146+ T cells were also predominantly negative for CD31. This further indicates that the observed staining was not due to lymphocyte-endothelial cell doublets, as the only endothelial marker expressed on the T cells was CD146. CD31, which can be expressed on T cells as well as endothelial cells, displayed infrequent costaining with CD146. In general, however, these two markers identified different subsets of T cells.

\section{Analysis of Chemokines, Chemokine Receptors, and Memory markers}

A paucity of CCR7 expression was found on CD146+ CD3 + T cells in peripheral blood from healthy volunteers (Figure 4). This was consistent for both CD4 and CD8 T cells. No consistent positive or negative correlation was found between CD146 and CCR5, CXCR3, or CXCR5. Analysis of CD45RA and CD45RO revealed that CD3+ CD146+ T cells were almost entirely CD45RA negative and primarily CD45RO positive; consistent with a memory phenotype. The expression of CD62L was variable on both CD146 positive and negative T cells.

\section{In vitro activation of $T$ cells}

A previous report by Pickl et al [5] demonstrated CD146 expression could be induced by in vitro activation of T cells with mitogen stimulation. To reproduce, and extend, these observations, peripheral blood mononuclear cells were cultured in vitro in the presence of PHA, PWM, ConA, or IL-2 for varying lengths of time up to 5 days. In some studies, $5 \mu \mathrm{M}$ carboxyfluorescein diacetate succinimidyl ester was added to the culture to study cell proliferation.

These experiments demonstrated that mitogen stimulation increased the number of T cells expressing CD146 (approximately 4 to 10 -fold) as well as increasing the mean intensity of the CD146 staining. The intensity of staining increased with every subsequent cell division up to the fifth division, as evidenced by the CFDASE costaining (Figure 5). Similar upregulation of CD146 expression on T cells was observed using IL-2 to activate the cells. 

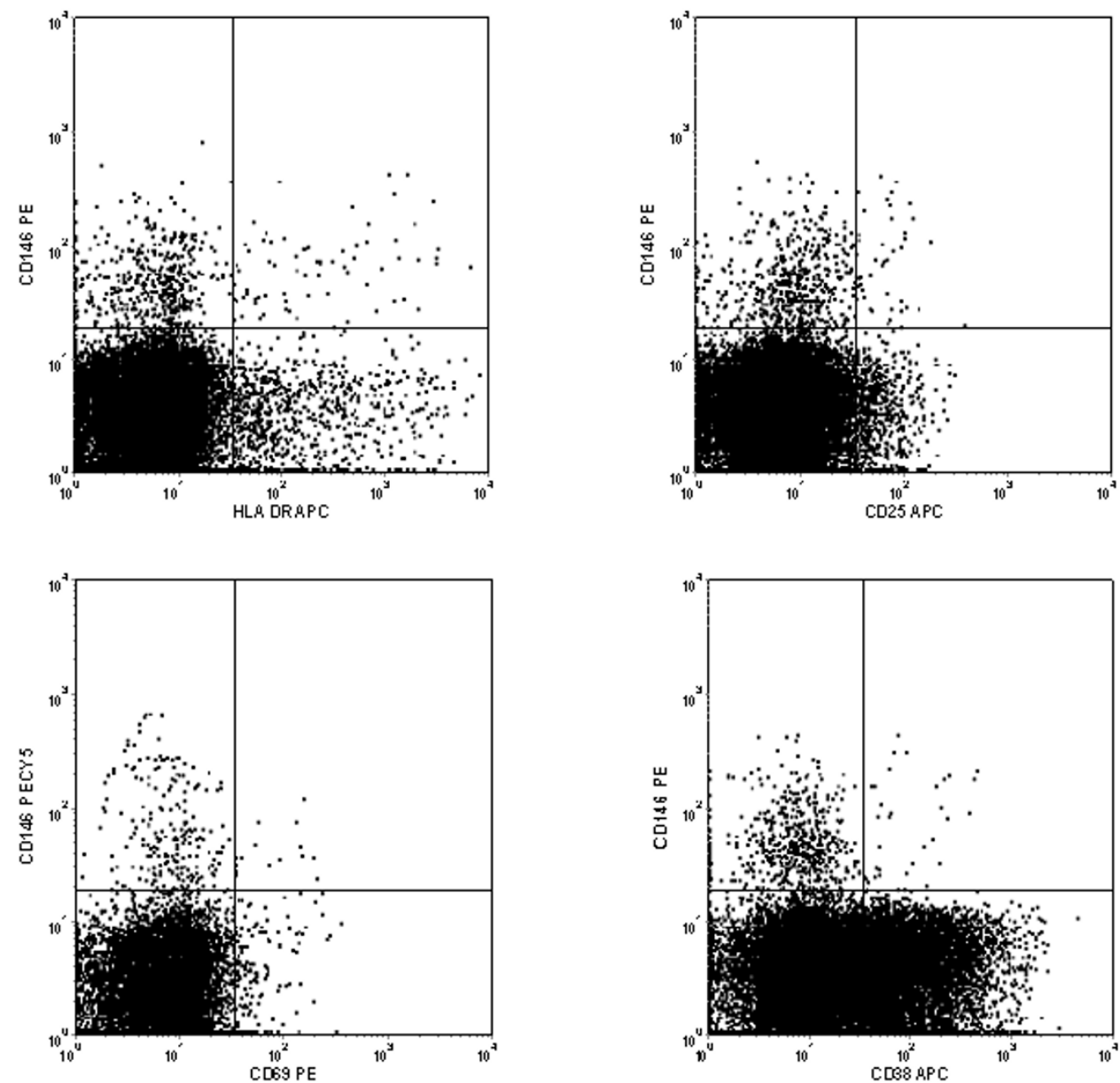

Figure 3

A. Representative histograms comparing CDI46 staining on CD3+ T cells to HLA-DR, CD25, CD69, and CD38, other common markers of activation. Only a small number of cells stained with both markers, indicating that largely unique subsets were identified by each. In healthy individuals, the percentage of HLA-Dr + T cells expressing CDI46 was $5.5 \%( \pm 1.99 \%$; $=5)$, the percentage of CD25+ T cell expressing CDI46 was 8.36\% ( $\pm 1.86 \%$; $n=5)$, the percentage of CD69+ T cells expressing CDI46 was $8.47 \%( \pm 3.08 \% ; n=5)$, and the percentage of CD38+ T cells expressing CD I 46 was $0.53 \%( \pm 0.19 \% ; n=4)$.

To determine if the increase in CD146 positive T cells observed above was due to expansion of preexisting CD146 positive cells or was due to de novo expression of CD146 on T cells that had previously been CD146 negative, cell sorting experiments were conducted. CD146 negative $\mathrm{T}$ cells were purified by flow cytometric cell sorting, and then cultured in vitro with mitogens, as above. In replicate experiments CD146 expression was induced by 72 hour mitogen stimulation in the sorted CD146 negative T cells.

\section{In vitro activation of $B$ cells}

Since there has been no report of CD146 expression on B lymphocytes, the observation that a very small percentage CD146 positive B cells in the circulation was unexpected.
To determine if the CD146 expression on B lymphocytes could be upregulated in a manner similar to that observed on $\mathrm{T}$ cells, freshly isolated $\mathrm{B}$ cells were activated in vitro with CD40L and IL-4. Similar to T cells activated in vitro, the activated $\mathrm{B}$ cells displayed increased numbers of CD146+ cells after 5 days of activation ( 5 to 10 fold), and the intensity of CD146 staining increased compared to the fresh cells. CD146 negative B cells, sorted by flow cytometry from either fresh peripheral blood or from populations of $\mathrm{B}$ cells activated in vitro, revealed de novo expression of CD146 after 5 days of in vitro activation.

In fresh blood peripheral blood B cells, CD146 expression displayed only a slight overlap with CD27, CD69, and HLADR staining. After activation with CD40L, virtually all 

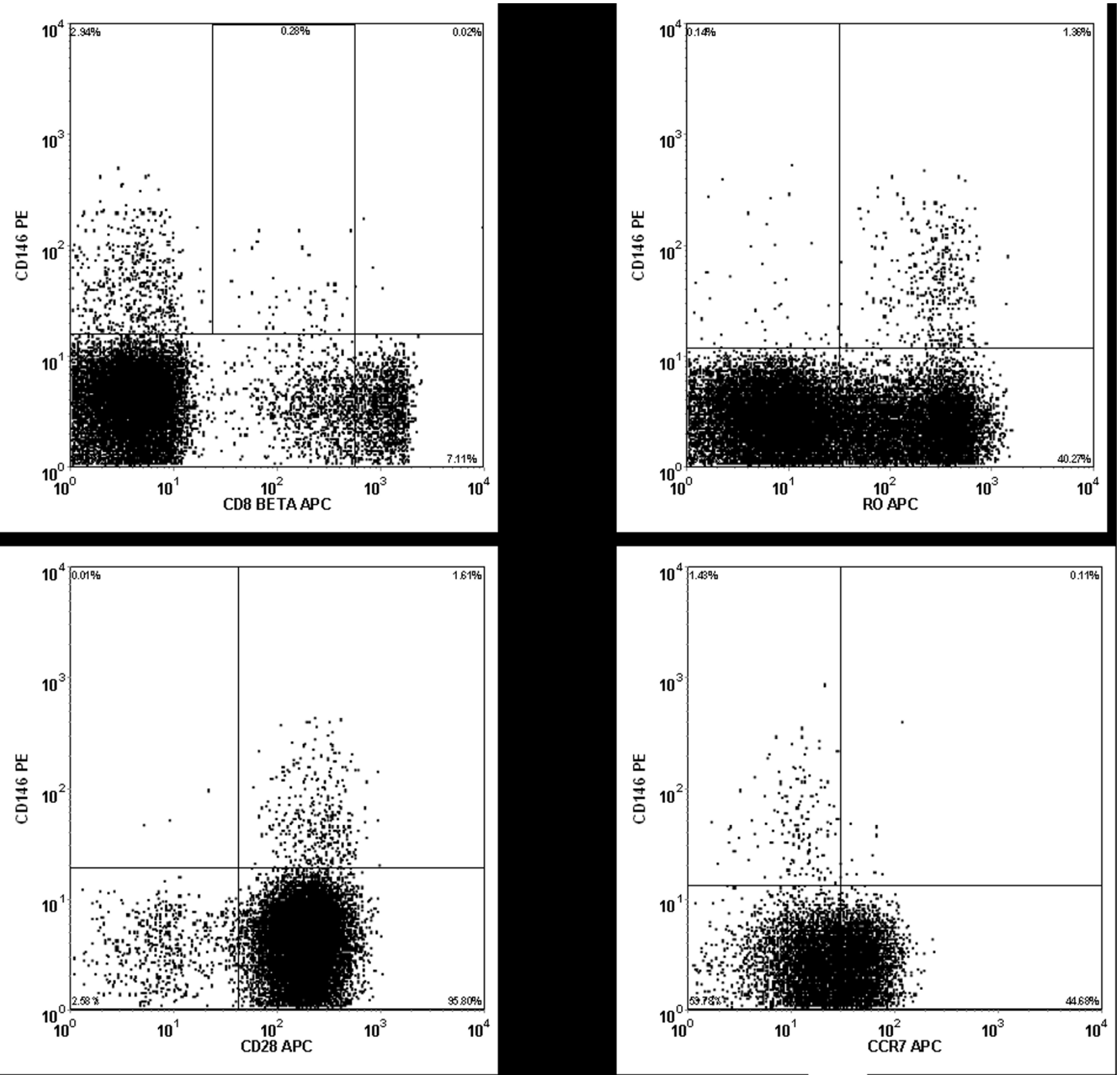

\section{Figure 4}

Representative histograms of CD3+ T cells stained with CDI46 and CD8 $\beta, C C R 7, C D 45 R O$, and CD28. Note that the majority of the CDI46+ T cells are CD28+, CD45RO+, CCR7-, and dim for CD8 $\beta$.

CD146+ B cells displayed co-staining with CD27, CD69, and HLA-DR.

\section{Adherence assays}

In order to assess whether CD146 positive T cells exhibited an increased ability to adhere to endothelial cells, in vitro binding assays were conducted. Lymphocytes were sorted into $\mathrm{CD} 3+\mathrm{CD} 146+$ and $\mathrm{CD} 3+\mathrm{CD} 146-$ popula- tions, and some aliquots of these cells were activated in vitro with PHA or pokeweed mitogen. Both activated and unactivated cells were then incubated on monolayers of activated HUVEC cells. These experiments (Figure 6) revealed that activation of $T$ cells substantially increased the number of cells capable of binding to the HUVECs and that, without stimulation, CD146+ T cells were more adherent than were CD146- T cells. The monolayers of 
HUVECs with attached $\mathrm{T}$ cells were also harvested and analyzed by flow cytometry (data not shown). These studies confirmed that the attached cells were T cells.

Blocking studies in which the activated T cells were preincubated with CD146 antibodies demonstrated a significant, but not complete, inhibition of the increased binding (Figure 6).

\section{Oligonucleotide microarray results}

Chip analysis of the RNA purified from the CD146 positive T cells and the CD146 negative T cells revealed substantial differences in the genes expressed between the two cell types. Using the predefined limits for significance (see Methods) a list of 104 probe sets comprising 84 unique genes was found. A list of the genes demonstrating the highest absolute log-fold changes in expression between the CD146+ T cells and the CD146- T cells, with the greatest statistical significance $(F D R \leq 0.005)$ is displayed in Table 1. The melanoma adhesion molecule, CD146, used as the basis for separating the two populations of $\mathrm{T}$ cells, ranked $38^{\text {th }}$ among genes preferentially expressed in CD146 positive $\mathrm{T}$ cells compared to the CD146 negative cells, with a 7 -fold change. Dual specificity phosphatases displayed some of the highest differences, with DSP-4 having a 5-fold increase in the CD146+ $\mathrm{T}$ cells. Many of the genes preferentially expressed by CD146+ T cells play roles related to signal transduction/ cell communication functions or are involved in the regulation of nucleobase, nucleoside, nucleotide, and nucleic

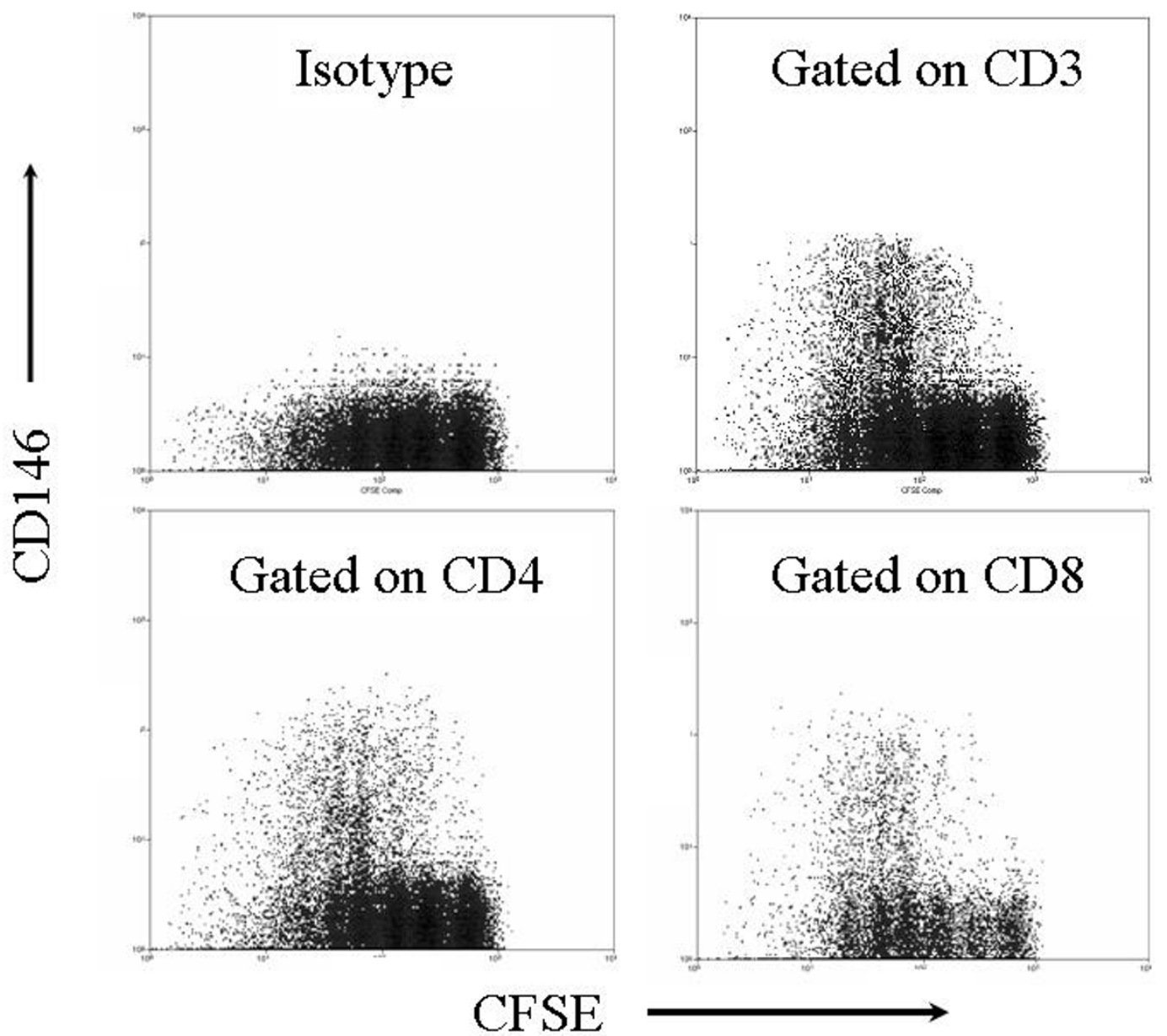

\section{Figure 5}

Mononuclear cells from the peripheral blood of a normal volunteer were incubated with carboxyfluorescein diacetatesuccinimidylester (CFSE) and PHA, as described in the text. CFSE fluorescence reduced with each cellular division. The cells were cultured a total of five days. The upper left panel displays CFSE staining versus a PE isotype control of CD3+ cells. The upper right panel shows staining of PECDI46 versus CFSE of CD3+ T cells. Lower panels display CFSE vs CD4 and CD8. CFSE staining decreased with each successive division of the T cells, and CDI46 expression increased. 
acid metabolism. Among the genes preferentially expressed in the CD146 negative T cells were the CD8 beta 1 chain, nitric oxide synthase interacting protein, and CCR7. There were some observed phenotypic correlations with the genotyping profile (Figure 4). Staining for CCR7, for example, revealed very little expression on CD146+ T cells, and CCR7 displayed a 6.3-fold association with CD146 negative cells. Similarly, CD8beta was negatively associated with CD146 by gene expression studies, and immunophenotyping revealed the vast majority of CD146+ $\mathrm{T}$ cells were either CD4+ or CD8beta low expressors (Figure 4). Some genotypic observations, such as the association of CD86 with CD146+ cells, did not correlate directly with immunophenotypic observations.
IPA analysis revealed a cluster of genes involved with the mechanisms of extravasation (Figure 7).

\section{Discussion}

To date CD146 expression on peripheral blood lymphocytes has only been described anecdotally, often in the context of attempts to detect circulating endothelial cells. In such situations CD146 positive lymphocytes merely represent confounding factors in accurately enumerating CECs, and no attempt has been made to characterize these cells. Since a primary function of CD146 on endothelial cells is to serve as an adhesion molecule for homotypic binding of these cells, it is a reasonable hypothesis to suggest that CD146 may perform a similar role on lym-

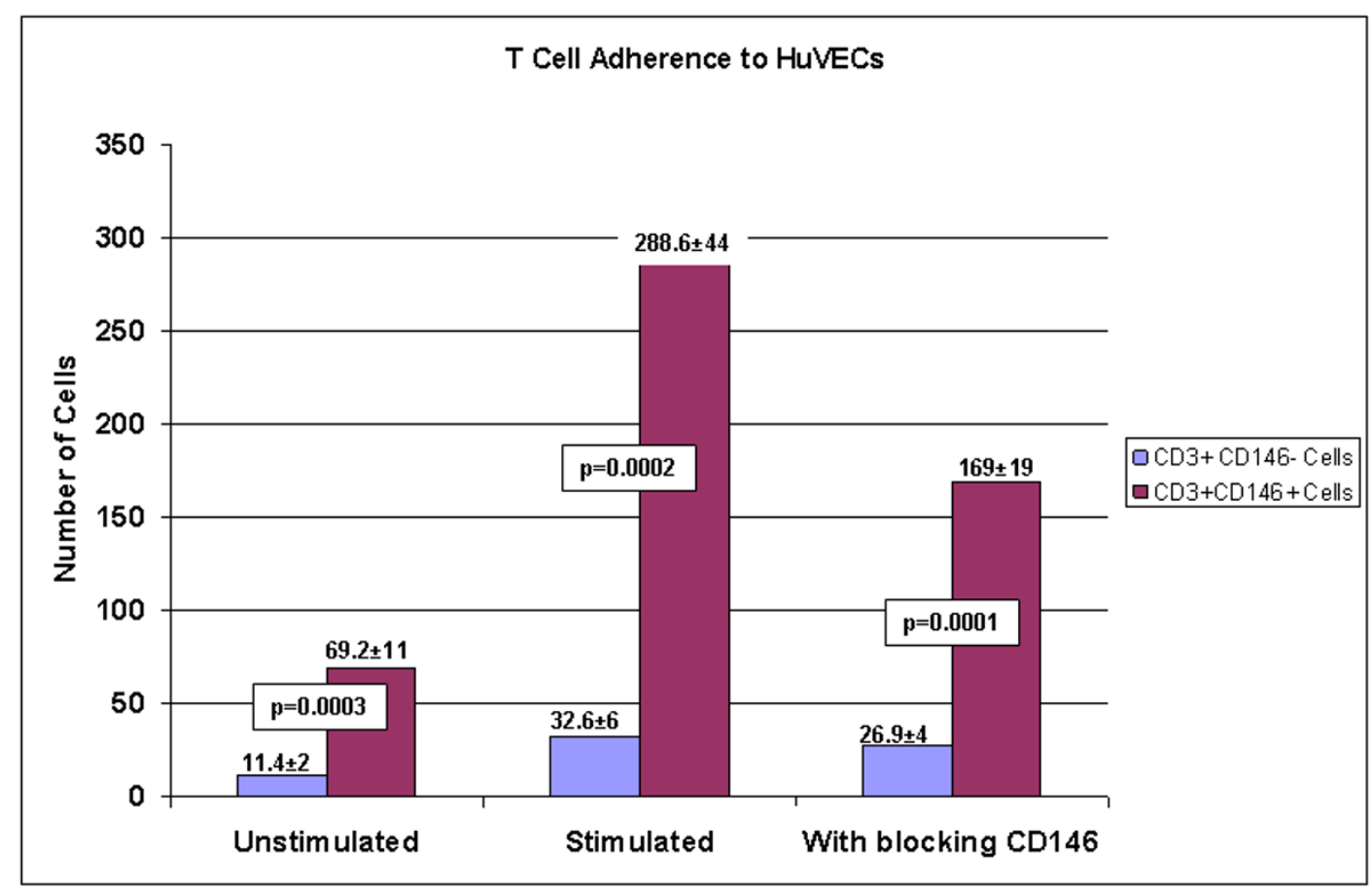

\section{Figure 6}

Adherence of $T$ cells to activated endothelial monolayers. Cells were sorted by flow cytometry into two populations - one was CD3+CDI46-, the other CD3+CDI46-+. Cells were tested without stimuation, with PHA stimulation, and with CDI46 blocking antibody following stimulation, as described in the methods. Data are shown as adhered cells per high powered field of light microscopy. The mean and standard deviations of 5 replicate experiments are shown. $\mathrm{P}$ values from paired t tests are shown. 
phocytes. It is well know that lymphocytes extravasate through the endothelium, particularly at sites of inflammation, although the precise mechanisms involved in this process have yet to be completely elucidated. It is possible that CD146 expression on lymphocytes plays a role in this process by mediating the binding of activated lymphocytes to the endothelium.

The current data indicate a distinct immunophenotype and gene profile of the Tlymphocytes expressing CD146. The expression of CD45RO together with the diminished of expression of CCR7 on CD3+ CD146+ T lymphocytes strongly suggests an effector memory role for these cells. This immunophenotype is consistent with cells predicted to home to inflamed, peripheral tissue sites of infection and thus generally supportive of the hypothesis offered above [11].

The gene profiling studies confirm the paucity of CCR7 on CD146+ T cells and further demonstrate that CD146+ cells have up-regulated a cluster of genes involved with adhesion, migration, homing, and ultimately inflammation as indicated in Ingenuity's Knowledge Database. The negative association of $\mathrm{CD} 8 \beta$ with CD146 expression is also of note in the gene profiling studies. While the majority of CD3 cells expressing CD146 were CD4+ and CD8-, all individuals tested did have CD3+CD8+ cells expressing CD146. Those CD8 T cells expressing CD146 were predominantly CD8 $\beta$-low. [12] reported CD28+ CD8 $\beta$-low, $\mathrm{CD} 45 \mathrm{RO}+$ lymphocytes displayed an activated, effector memory phenotype, consistent with the present data.

The current data indicate that CD146 + T cells adhere better than CD146- T cells to HuVEC endothelial monolayers in vitro, and that this binding is at least partially blocked through the use of CD146 antibodies. This enhanced ability of CD146+ T cells to bind to endothelium is also consistent with the proposed role for these cells in vivo. However, these data are at best suggestive, and much work remains to be done in order to demonstrate if, and how, CD146 T cells extravasate. Anecdotal observations by Pickl and colleagues [5] found elevated numbers of CD146+ T cells in the synovial fluid of patients with rheumatoid arthritis as well as in skin lesions of delayed-type hypersensitivity reactions. Preliminary studies from our group confirm the presence of elevated number of CD146+ T cells in inflammatory synovial fluids (data not shown).

The lack of correlation of the expression of CD146 with other common markers of lymphocyte activation (CD69, CD25, and HLA-Dr) is somewhat unexpected. The CD146+ T cell thus represent a distinct population of activated cells in the peripheral circulation that have heretofore not been characterized.
In addition to its role as a cell adhesion molecule, CD146 has also been found to be associated with functional changes in endothelial cells. Notably, CD146 has been demonstrated to be involved in a complex outside-in signaling pathway [2]. In endothelial cells, engagement of CD146 by monoclonal antibody initiates calcium mobilization leading to tyrosine phosphorylation of Pyk2, p130 Cas, FAK, and paxillin. Solvey and colleagues [1] confirmed many of these findings and found that CD146 binding led to a change in cellular permeability, actin distribution, and redistribution of NF- $\mathrm{KB}$ p50 to the nucleus. The current data indicate that a number of genes involved in signal transduction and cell communication are upregulated in the CD146 positive T cells. Given the previous reports, it is reasonable to postulate that engagement of CD146 on the surface of T cells might also lead to outsidein signaling pathways in lymphocytes. In endothelial cells these pathways lead to changes in permeability and cytoskeletal rearrangement - pathways, if also present in lymphocytes, would likely be necessary to facilitate transendothelial migration.

\section{Conclusion}

The present data show that CD146 is an inducible activation antigen on both $\mathrm{B}$ and $\mathrm{T}$ lymphocytes and small populations of these cells are present in the peripheral circulation of healthy individuals. The CD146+ T cells have an effector memory phenotype, demonstrate up-regulation of a cluster of genes involved with adhesion, migration, homing, and inflammation, and have enhanced binding to endothelial monolayers in vitro. All of these characteristics are consistent with cells involved in inflammatory responses. Based on the polyclonal nature of the CD146+ T cells in the peripheral circulation, we speculate that these represent a small pool of cells primed for extravasation in response to inflammatory stimuli.

\section{Methods \\ Collection of blood}

Peripheral blood was collected by routine venipuncture from healthy volunteers. Blood draws were obtained under a protocol approved by the National Heart, Lung, and Blood Institute Institutional Review Board. Acid citrate dextrose $(\mathrm{ACD})$ or sodium heparin was used as the anticoagulant.

\section{Immunofluorescence staining}

Stimulated or freshly isolated peripheral blood mononuclear cells (PBMCs) were washed and then surface stained with directly conjugated antibodies to CD146 and other surface markers (isotype matched, control monoclonal antibodies, or mouse antihuman CD2, CD3, CD4, CD7, CD8, CD8 $\beta$ CD10, CD14, CD19, CD20, CD25, CD28, CD29, CD31, CD34, CD38, CD45, CD45RA, CD45RO, 
Table I: List of 66 genes with the largest log fold changes between CDI46 positive and CDI46 negative T cells.

\begin{tabular}{|c|c|c|c|c|}
\hline Rank & Gene & $\begin{array}{l}\text { Fold Increase } \\
\text { (or decrease) } \\
\text { CD3+CD I 46+/ } \\
\text { CD3+CD I46- }\end{array}$ & Function* & Process* \\
\hline I & Dual specificity phosphatase 4 & 65 & Protein phosphatase activity & $\begin{array}{l}\text { Signal transduction/cell } \\
\text { communication }\end{array}$ \\
\hline 2. & Regulator of G-protein signaling I & 41.8 & GTPase activator & $\begin{array}{l}\text { Signal transduction/cell } \\
\text { communication }\end{array}$ \\
\hline 3 & $\begin{array}{l}\text { Nuclear receptor subfamily } 4 \text {, group } \\
\text { A member } 2\end{array}$ & 35.7 & Ligand-dependent nuclear receptor & $\begin{array}{l}\text { Signal transduction/cell } \\
\text { communication }\end{array}$ \\
\hline 4 & $\begin{array}{l}\text { v-jun sarcoma virus } 17 \text { oncogene } \\
\text { homolog }\end{array}$ & 22.5 & - & - \\
\hline 5 & Kruppel-like factor 10 & 22.3 & Transcription factor activity & $\begin{array}{l}\text { Regulation of nucleobase, nucleoside } \\
\text { metabolism }\end{array}$ \\
\hline 6 & $\begin{array}{l}\text { Chromosome } 10 \text { open reading } \\
\text { frame } 128\end{array}$ & 20.6 & Unknown & Unknown \\
\hline 7 & Dual specificity phosphatase I & 19.9 & Protein phosphatase activity & $\begin{array}{l}\text { Signal transduction/cell } \\
\text { communication }\end{array}$ \\
\hline 8 & Interleukin 8 & 19.1 & Cytokine & Immune response \\
\hline 9 & RAR-related orphan receptor C & 18.1 & Ligand-dependent nuclear receptor & $\begin{array}{l}\text { Regulation of nucleobase, nucleoside } \\
\text { metabolism }\end{array}$ \\
\hline 10 & $\begin{array}{l}\text { Family with sequence similarity } 46 \text {, } \\
\text { member C }\end{array}$ & 15 & Unknown & Unknown \\
\hline 11 & $\begin{array}{l}\text { FBJ murine osteosarcoma viral } \\
\text { oncogene homolog B }\end{array}$ & 13.6 & Transcription factor activity & $\begin{array}{l}\text { Regulation of nucleobase, nucleoside } \\
\text { metabolism }\end{array}$ \\
\hline 12 & Pre-B-cell colony enhancing factor I & 12.3 & Cytokine & $\begin{array}{l}\text { Signal transduction/cell } \\
\text { communication }\end{array}$ \\
\hline 13 & A kinase (PRKA) anchor protein 2 & 11.9 & Cytoskeletal anchor & Cell growth and/or maintenance \\
\hline 14 & Pellino homolog I & 11.5 & $\begin{array}{l}\text { Receptor signaling complex scaffold } \\
\text { activity }\end{array}$ & $\begin{array}{l}\text { Signal transduction/cell } \\
\text { communication }\end{array}$ \\
\hline 15 & Chimerin I & 11.1 & GTPase activator activity & $\begin{array}{l}\text { Signal transduction/cell } \\
\text { communication }\end{array}$ \\
\hline 16 & $\begin{array}{l}\text { Solute carrier family } 6 \text {, } \\
\text { neurotransmitter transporter, } \\
\text { GABA, member } 13\end{array}$ & 10.7 & Auxiliary transport protein activity & Transport \\
\hline 17 & Tribbles homolog I & 10.4 & Protein kinase activity & $\begin{array}{l}\text { Signal transduction/cell } \\
\text { communication }\end{array}$ \\
\hline 18 & Integrin beta I (fibronectin receptor) & 9.7 & Receptor activity & $\begin{array}{l}\text { Signal transduction/cell } \\
\text { communication }\end{array}$ \\
\hline 19 & Rho GTPase activating protein 10 & 9.6 & GTPase activator activity & $\begin{array}{l}\text { Signal transduction/cell } \\
\text { communication }\end{array}$ \\
\hline 20 & $\begin{array}{l}\text { Phorbol- I 2-myristate- I3-acetate- } \\
\text { induced protein I }\end{array}$ & 9.5 & Unknown & Apoptosis \\
\hline 21 & $\begin{array}{l}\text { Tumor necrosis factor alpha-induced } \\
\text { protein } 3\end{array}$ & 9.3 & Transcription regulator activity & $\begin{array}{l}\text { Regulation of nucleobase, nucleoside } \\
\text { metabolism }\end{array}$ \\
\hline 22 & CD83 antigen & 9.2 & Unknown & Immune response \\
\hline 23 & $\begin{array}{l}\text { DEAD (asp-Glu-Ala-Asp) box } \\
\text { polypeptide } 31\end{array}$ & 8.6 & RNA binding & $\begin{array}{l}\text { Regulation of nucleobase, nucleoside } \\
\text { metabolism }\end{array}$ \\
\hline 24 & $\begin{array}{l}\text { Similar to RIKEN cDNA } \\
\text { |2000 |4N } 16 \text { gene }\end{array}$ & 8.2 & Unknown & Unknown \\
\hline 25 & Cyclin LI & 8.2 & RNA binding & $\begin{array}{l}\text { Regulation of nucleobase, nucleoside } \\
\text { metabolism }\end{array}$ \\
\hline 26 & $\begin{array}{l}\text { Alpha thalassemia/mental } \\
\text { retardation syndrome } X \text {-linked }\end{array}$ & 7.9 & - & - \\
\hline 27 & $\begin{array}{l}\text { Pvtl oncogene homolog, MYC } \\
\text { activator }\end{array}$ & 7.7 & - & - \\
\hline 28 & SNFI-like kinase & 7.7 & Protein kinase activity & $\begin{array}{l}\text { Signal transduction/cell } \\
\text { communication }\end{array}$ \\
\hline 29 & $\begin{array}{l}\text { Basic helix-loop-helix domain } \\
\text { containing class B, } 2\end{array}$ & 7.6 & Transcription regulator activity & $\begin{array}{l}\text { Regulation of nucleobase, nucleoside } \\
\text { metabolism }\end{array}$ \\
\hline 30 & Phytoceramidase, alkaline & 7.6 & Hydrolase activity & Metabolism;energy pathways \\
\hline 31 & BTG family, member 3 & 7.4 & Regulation of cell cycle & $\begin{array}{l}\text { Signal transduction/cell } \\
\text { communication }\end{array}$ \\
\hline
\end{tabular}


Table I: List of 66 genes with the largest log fold changes between CD I 46 positive and CD I 46 negative T cells. (Continued)

\begin{tabular}{|c|c|c|c|c|}
\hline 32 & Runt-related transcription factor I & 7.4 & Transcription factor activity & $\begin{array}{l}\text { Regulation of nucleobase, nucleoside } \\
\text { metabolism }\end{array}$ \\
\hline 33 & $\begin{array}{l}\text { Phosphodiesterase 4D, c-AMP- } \\
\text { specific }\end{array}$ & 7.2 & Phosphoric diester hydrolase activity & $\begin{array}{l}\text { Signal transduction/cell } \\
\text { communication }\end{array}$ \\
\hline 34 & SKI-like & 7.2 & unknown & $\begin{array}{l}\text { Signal transduction/cell } \\
\text { communication }\end{array}$ \\
\hline 35 & $\begin{array}{l}\text { DEAD (asp-Glu-Ala-Asp) box } \\
\text { polypeptide } 59\end{array}$ & 7.2 & RNA binding & $\begin{array}{l}\text { Regulation of nucleobase, nucleoside } \\
\text { metabolism }\end{array}$ \\
\hline 36 & Dynamin 3 & 7.1 & GTPase activity & $\begin{array}{l}\text { Signal transduction/cell } \\
\text { communication }\end{array}$ \\
\hline 37 & $\begin{array}{l}\text { Interferon-related Developmental } \\
\text { regulator I }\end{array}$ & 7.1 & Receptor binding & $\begin{array}{l}\text { Signal transduction/cell } \\
\text { communication }\end{array}$ \\
\hline 38 & Bicaudal D homolog I & 7 & Transporter activity & Transport \\
\hline 39 & Melanoma cell adhesion molecule & 7 & Cell adhesion molecule & $\begin{array}{l}\text { Signal transduction/cell } \\
\text { communication }\end{array}$ \\
\hline 40 & $\begin{array}{l}\text { Clone IMAGE: I I02I8 mRNA } \\
\text { sequence }\end{array}$ & 6.9 & - & - \\
\hline 41 & $\begin{array}{l}\text { Trophoblast-derived noncoding } \\
\text { RNA }\end{array}$ & 6.9 & - & - \\
\hline 42 & $\begin{array}{l}\text { CDNA clone IMAGE: } 4077090, \\
\text { partial cds }\end{array}$ & 6.7 & - & - \\
\hline 43 & $\begin{array}{l}\text { Hydroprostaglandin dehydrogenase } \\
\text { I5-(NAD) }\end{array}$ & 6.6 & & \\
\hline 44 & PERP, TP53 apoptosis effector & 6.5 & Unknown & Apoptosis \\
\hline 45 & Hypothetical protein MGCI4376 & 6.4 & Unknown & Unknown \\
\hline 46 & Interleukin I receptor, type I & 6.2 & Transmembrane receptor activity & $\begin{array}{l}\text { Signal transduction/cell } \\
\text { communication }\end{array}$ \\
\hline 47 & Ring finger protein 10 & 6.1 & Ubiquitin-specific protease activity & Protein metabolism \\
\hline 48 & $\begin{array}{l}\text { Protein phosphatase } 2 \text {, regulatory } \\
\text { subunit } \mathrm{B}(\mathrm{B} 56) \text { gamma isoform }\end{array}$ & 6 & - & - \\
\hline 49 & $\begin{array}{l}\text { Protein tyrosine phosphatase, non- } \\
\text { receptor type } 13\end{array}$ & 6 & Protein tyrosine phosphatase activity & $\begin{array}{l}\text { Signal transduction/cell } \\
\text { communication }\end{array}$ \\
\hline 50 & $\begin{array}{l}\text { v-ets erythroblastosis virus E26 } \\
\text { oncogene homolog I }\end{array}$ & 5.9 & Transcription factor activity & $\begin{array}{l}\text { Regulation of nucleobase, nucleoside } \\
\text { metabolism }\end{array}$ \\
\hline 51 & DKFZP586A0522 protein & 5.8 & Methyltransferase activity & Metabolism; energy pathways \\
\hline 52 & $\begin{array}{l}\text { Similar to echinoderm microtubule } \\
\text { associated protein like } 5\end{array}$ & 5.8 & - & - \\
\hline 53 & Hypothetical protein FLJ43663 & 5.8 & Unknown & Unknown \\
\hline 54 & Deleted in lymphocytic leukemia, 2 & 5.8 & Unknown & Cell growth and/or maintenance \\
\hline 55 & CDNA clone IMAGE: 3542720 & 5.8 & - & - \\
\hline 56 & Tetratricopeptide repeat domain 8 & 5.6 & Unknown & Cell growth and/or maintenance \\
\hline 57 & $\begin{array}{l}\text { DNA polymerase-transactivated } \\
\text { protein } 6\end{array}$ & 5.6 & Unknown & Unknown \\
\hline-9 & Ribosomal protein SII & $1 / 5.6$ & Ribosomal subunit & Protein metabolism \\
\hline-8 & Ribosomal protein 59 & $1 / 6.2$ & Ribosomal subunit & Protein metabolism \\
\hline-7 & Hypothetical protein MGC40I57 & $1 / 6.2$ & Unknown & Unknown \\
\hline-6 & Chemokine ( $\mathrm{C}-\mathrm{C}$ motif) receptor 7 & $1 / 6.3$ & G coupled protein receptor & $\begin{array}{l}\text { Signal transduction/cell } \\
\text { communication }\end{array}$ \\
\hline-5 & $\begin{array}{l}\text { ATPase, } \mathrm{H}+\text { transporting lysosomal } \\
9 \mathrm{kDa} \text {, V0 subunit e }\end{array}$ & $1 / 6.5$ & ATPase activity & Transport \\
\hline-4 & Ribosomal protein L28 & 1/6.6 & Ribosomal subunit & Protein metabolism \\
\hline-3 & $\begin{array}{l}\text { Nitric oxide synthase interacting } \\
\text { protein }\end{array}$ & I/7.3 & Transporter activity & Transport \\
\hline-2 & CD8 antigen, beta polypeptide I & I/7.7 & $\mathrm{T}$ cell receptor activity & Immune response \\
\hline-1 & Hypothetical protein FLJI4346 & $1 / 8.5$ & Unknown & Unknown \\
\hline
\end{tabular}

*from the Human Protein Reference Database http://www.hprd.org 


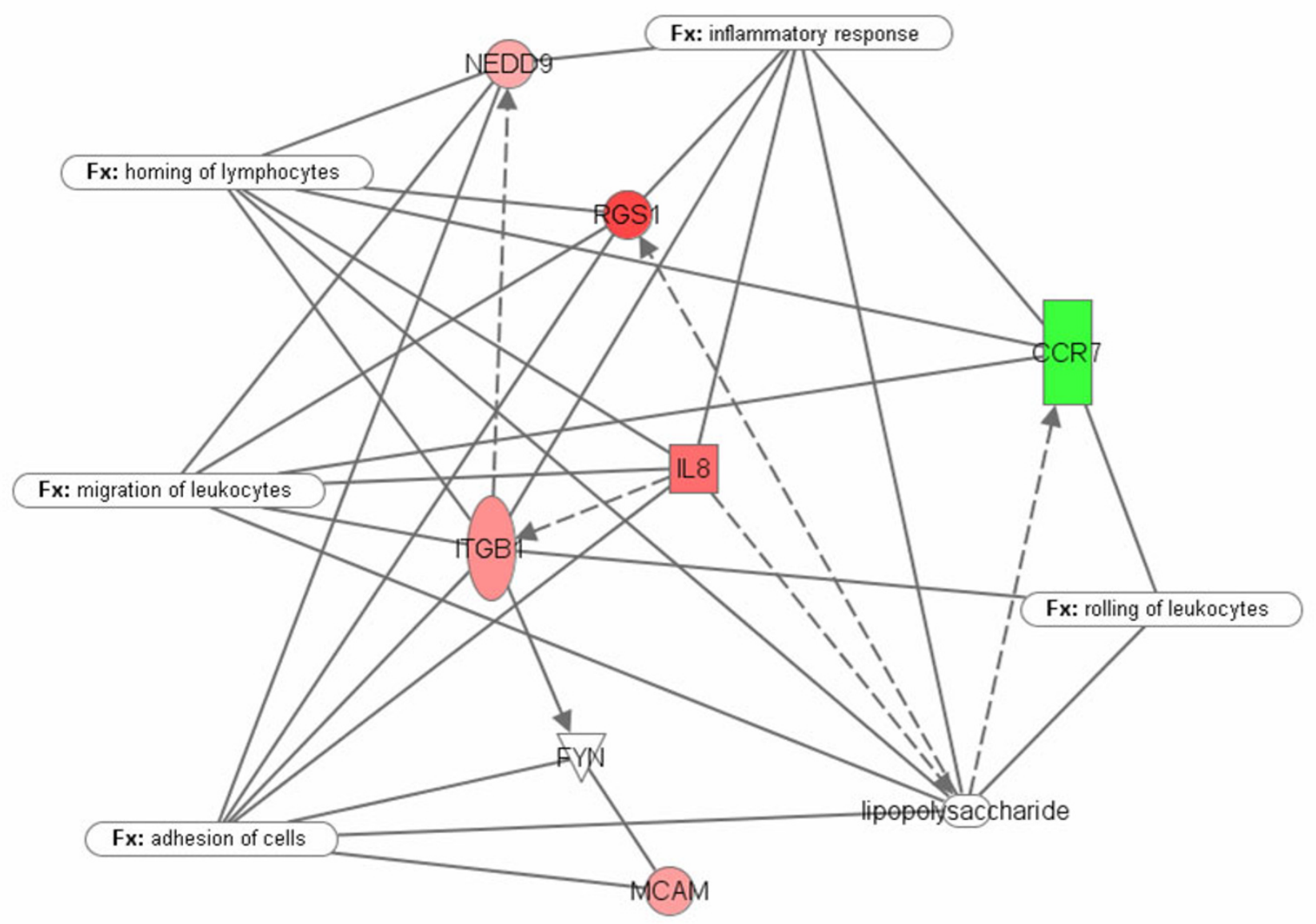

Figure 7

The microarray studies and analysis by Ingenuity ${ }^{\mathrm{TM}}(2 \mathrm{I})$ showed that $C D+146$ cells up-regulate a cluster of genes (red) that prepare them for the mechanisms of extravasation and destination to an inflammatory site. The green down-regulated gene (CCR7) indicates capability for the reverse migration, i.e. from peripheral tissues into vasculature or into lymphatics

CD62L, CD69, CD83, CCR7, CCR5, CXCR5, CXCR3, and HLA-DR monoclonal antibodies (all from Becton Dickinson Immunocytometry Systems, San Jose, CA) according to the manufacturer's instructions. FITC-CD166 was purchased from Ancell (North Bayport, MN) and APCCD133 from Miltenyi Biotec GmbH (Auburn, CA). Additionally, PE-conjugated CD146 purchased from Chemicon was used in some experiments to compare to the $\mathrm{BD}$ antibody. Stained cells were washed three times with $1 \%$ BSA in PBS, pH 7.2, and then 7AAD (Beckman Coulter, Hialeah, FL) was added to stain dead cells. The cells were analyzed within 15 minutes after addition of 7AAD. In some experiments with fresh peripheral blood not requiring viability staining, a stain-lyse method was followed using FACSLyse (BDIS) as per the manufacturer's instructions.
$\mathrm{T}$ cell $\mathrm{v} \beta$ usage by CD146 positive cells was examined using monoclonal antibodies to various $\mathrm{v} \beta$ families in immunophenotypic studies. The following antibodies were purchased from Beckman Coulter (Hialeah, FL): $\mathrm{v} \beta 2,3,5.1,5.2,5.3,7,8,9,11,12,13.1,13.6,14,16,17$, 20 , pan $\alpha \beta$, and pan $\gamma \delta$.

\section{Flow Cytometric Immunophenotyping and cell sorting}

Flow cytometric analysis was performed using a DakoCytomation CyAn (DakoCytomation, Fort Collins, CO) or a FACSCalibur (Becton Dickinson, San Jose, CA). Fluorescein isothiocyanate (FITC) or carboxyfluorescein diacetate succinimidylester (CFDASE), phycoerythrin (PE), PETexas Red, \&-aminiactinimmycin-D (7-AAD [for viability staining]), PE-Cy7, allophycocyanin (APC) and APC-Cy7 were used as the fluorophores. At least 50,000 live CD3+ 
lymphocytes were collected on each sample for analysis. Gates were set using light scatter and for live cells using 7AAD exclusion.

Cell sorting experiments were performed on cells stained as described. Both the FACSAria (Becton Dickinson) and the MoFlo (Dako Cytomation) cell sorters were used for these experiments. Pulse width was used to eliminate doublets on all sorts, to eliminate the possible isolation of endothelial cell-lymphocyte duplexes (derived from 9). Populations of cells that were sorted were: CD45+CD3+CD146+; CD45+D3+CD146-; CD45+CD19 +CD146+; and CD45+CD19+CD146-. A minimum of 3,000 cells were sorted for the gene profiling studies, and a minimum of 100,000 were sorted for the in vitro activation studies. CD146 positive T cells were obtained from five individuals, and CD146 negative T cells were examined from three of these five. B cell subpopulations were sorted from another 3 healthy individuals.

\section{$T$ cell culture and activation}

Peripheral blood mononuclear cells (PBMCs), obtained by density gradient separation, were washed and resuspended at a density of $0.5 \times 10^{6}$ cells per mL in RPMI 1640 medium containing 10\% FCS (HyClone, Logan, UT), 25 $\mathrm{mM}$ Hepes, $2 \mathrm{mM}$ Lglutamine, $100 \mathrm{IU} / \mathrm{mL}$ of penicillin, $100 \mu \mathrm{g} / \mathrm{mL}$ streptomycin, and $5 \mu \mathrm{M} 2$ mercaptoethanol. T cell activation was achieved by the addition of either phytohemagglutinin (PHA), concannavalin A (Con A), or pokeweed mitogen (PWM) (Sigma, St. Louis, MO) at 5 $\mu \mathrm{g} / \mathrm{mL}$, as described previously [5]. After 3 days cells were washed twice and resuspended in media with $10 \mu \mathrm{l} / \mathrm{mL}$ IL-2 (R\&D, Minneapolis, MN) without further stimulation. Cells were passaged every 2 to 3 days, replenishing IL-2 with every passage. In some experiments, CFDASE was added to the cells to examine proliferation, as described below.

$\mathrm{T}$ cell culture and activation studies were also conducted on CD3+CD146cells sorted by flow cytometry. These were performed as described above to determine if CD146 expression in vitro could emanate de novo from a starting population of cells that were CD146 negative.

\section{B cell culture and activation}

$B$ cells were expanded from healthy donor PBMCs using CD40 ligand-transfected NIH3T3 cells (t-CD40L) as previously described $[13,14]$ Briefly, $2 \times 10^{5}$ irradiated $(75$ Gy) t-CD40L cells (kindly provided by Dr M. Nishimura, University of Chicago) were plated into 6-well plates (Costar, Cambridge, MA) and cultured overnight at $37^{\circ} \mathrm{C}$ in $5 \% \mathrm{CO} 2$. The following day, media were removed, and $4 \times 10^{6}$ to $6 \times 10^{6}$ PBMCs suspended in $3 \mathrm{~mL}$ Iscove-modified Dulbecco medium (IMDM) (Cellgro; Mediatech, Herndon, VA) supplemented with $10 \%$ pooled human serum, IL-4 (200 U/mL; PeproTech USA, Rocky Hill, NJ), and clinical grade CSA $\left(5.5 \times 10^{7} \mathrm{M}\right.$; Novartis, Basel, Switzerland) were added to each well and cultured at $37^{\circ} \mathrm{C}$ in $5 \%$ CO2. Approximately every 3 to 4 days, expanded B cells were washed and then transferred onto freshly prepared irradiated t-CD40L cells in cytokine replenished medium. Expanded B cells were checked CD146 expression by flow cytometry on Days 7-8.

\section{Carboxyfluorescein diacetate succinimidylester cell labeling and culture conditions}

To examine CD146 expression as a function of cell division, PBMCs were labeled with CFDASE during growth in vitro for 5 days (method reviewed in 15). Cells were stimulated with PHA as described above. Prior to incubation, PBMCs were washed and resuspended at a density of $2 \times$ $10^{7}$ cells per $\mathrm{mL}$ in PBS. An equal volume of $5 \mu \mathrm{M}$ carboxyfluorescein diacetate succinimidyl ester (CFDASE; Molecular Probes, Inc., Eugene, OR) in PBS was added, and the cells were gently mixed for $15 \mathrm{~min}$ at $37^{\circ} \mathrm{C}$. Unbound CFDASE, or the deacetylated form, CFSE, was quenched by the addition of an equal volume of fetal bovine serum (FBS). Analysis of cells immediately following CFSE labeling indicates a labeling efficiency that exceeded 99\%, and all cells remain labeled for at least 5 days.

The labeled cells were washed two times in PBS and resuspended at $1 \times 10^{6}$ cells per mL in RPMI 1640 medium containing 10\% FCS (HyClone, Logan, UT), 25 mM Hepes, 2 $\mathrm{mM}$ L-glutamine, $100 \mathrm{IU} / \mathrm{mL}$ of penicillin, $100 \mu \mathrm{g} / \mathrm{mL}$ streptomycin, and $5 \mu \mathrm{M} 2$ mercaptoethanol. Labeled cells were plated at $1 \times 10^{5}$ cells per well in round bottom 96 well microtiter plates, and $\mathrm{T}$ cell activation was achieved by the addition of phytohemagglutinin (PHA) (Sigma) or Con A (Sigma) at $5 \mu \mathrm{g} / \mathrm{mL}$.

\section{Endothelial Cell Culture}

HUVEC (human umbilical vascular endothelial cells, Cambrex) were cultured in $\mathrm{EGM}^{\mathrm{TM}} 2 \mathrm{MV}$ medium (Cambrex) in BD Falcon Tissue Culture flasks and subcultured at 50 to $70 \%$ confluence before harvesting for analysis or culture in 24-well plates for adherence assays.

\section{Adherence Assays}

Peripheral blood mononuclear cells prepared and stained, as described above, were sorted into CD3+CD146+ and CD3+ CD146- populations. These populations were suspended in $600 \mu \mathrm{l} \mathrm{RPMI}$ (plus 10\% FCS) and incubated either with or without $5 \mu \mathrm{g} / \mathrm{mL}$ PHA for 72 hours at $37^{\circ} \mathrm{C}$ with $5 \% \mathrm{CO}_{2}$ prior to the adherence assay (modified from 16). The cells were washed twice with $2 \mathrm{~mL}$ RPMI (plus $10 \%$ FCS) and finally resuspended at $1 \times 10^{6} \mathrm{cells} / \mathrm{mL}$ in RPMI (plus 10\% FCS). HUVEC cells, grown to confluency in 24-well plates (with or without Transwell inserts), were 
used to assess adherence. HUVECs were activated by exposure to $1 \mathrm{ng} / \mathrm{ml} \mathrm{IL-1B}$ in medium (RPMI/I0\% FCS) for 4 hours at $37^{\circ} \mathrm{C}$ and then washed once with medium immediately before addition of T cells. [17]. The medium was aspirated from each well and replaced with $500 \mu \mathrm{l}$ of either CD146+ or CD146- T cells $\left(1 \times 10^{6} \mathrm{cell} / \mathrm{ml}\right)$. Each test was performed in duplicate. After 1 hour incubation at $37^{\circ} \mathrm{C}$, loosely adherent cells were removed by washing the monolayers 3 times with $500 \mu \mathrm{l}$ RPMI. The numbers of adherent lymphocytes were enumerated using light microscopy by counting small rounded cells atop the endothelial monolayers per high power field. A minimum of 10 fields were counted in each experiment and averaged.

\section{Antibody Blocking Studies}

Experiments were conducted to determine the effect of blocking the lymphocyte CD146 surface antigen on the binding of these cells to activated endothelial monolayers. Lymphocytes, at a concentration of $10 \times 10^{6} \mathrm{cells} / \mathrm{mL}$ in culture media were incubated with anti-CD146 (clone P1H12, BD Pharmingen, San Jose, CA) $\left(20 \mu \mathrm{g} / 10^{6}\right.$ cells $)$ for $45 \mathrm{~min}$ at $37^{\circ} \mathrm{C}$. The cells were washed once and resuspended at $1 \times 10^{6}$ cells $/ \mathrm{mL}$ before addition to the endothelial monolayers. The adherence assays were then performed as described above.

\section{Isolation of RNA from Flow Sorted Cells}

Cells were collected in lysis buffer containing guanidinium thiocyanate and total RNA was extracted using RNAqueous micro RNA isolation kit (Ambion, Austin, TX) following the manufacturer's directions. In brief, cell lysate was mixed with ethanol and applied to a silica based filter that selectively binds RNA. Genomic DNA from the eluted RNA was removed by DNase treatment. The concentration of the isolated RNA was determined using a nanodrop ND-1000 spectrophotometer. Quality and integrity of total RNA was assessed on an Agilent 2100 bioanalyzer.

\section{Amplification of RNA and Gene Expression studies}

Linear T7 based RNA amplification was carried out on 10 ng of the isolated total RNA using Riboamp OA 2 round amplification kit as suggested by the manufacturer (Arcturus, Mountain View, CA). Briefly, total RNA was incubated with oligo dT/T7 primers and reverse transcribed into double stranded cDNA. In vitro transcription of the purified cDNA was performed using T7 RNA polymerase at $42^{\circ} \mathrm{C}$ for 6 hours. The amplified RNA was purified and subjected to a second round of amplification with biotin labeling using Affymetrix's IVT labeling kit following the manufacturer's directions. The yield and integrity of the biotin labeled cRNA were determined using Nanodrop ND-1000 spectrophotometer and Agilent 2100 bioanalyzer. Biotin labeled RNA $(20 \mu \mathrm{g})$ was fragmented to $\sim 200$ bp size by incubating in $200 \mathrm{mM}$ Tris-Acetate $\mathrm{pH}$ 8.2, 500 $\mathrm{mM}$ KOAc, MgOAc fragmentation buffer for $35 \mathrm{~min}$ at $94^{\circ} \mathrm{C}$ prior to hybridization. Fragmented cRNA was assessed for fragment size on Agilent 2100 bioanalyzer and hybridized to Affymetrix U133A plus 2.0 chips for 16 hours, and the hybridized gene chips were washed and stained on an Affymetrix fluidics station.

\section{Microarray Data Processing and Statistical Analysis}

Affymetrix GCOS version 1.2 software was used to calculate signal and present call values which were stored in the NIHLIMS, a database for storage and retrieval of chip data maintained at NIH. Data were statistically analyzed using the MSCL Analyst's Toolbox [18] and the JMP statistical software package (SAS, Inc, Cary, NC). The results for 8 chips were retrieved and signal values were subjected to an adaptive variance-stabilizing, quantile-normalizing transformation termed "S10" [19]. This transform both normalizes between chips over the full data range, and makes the variance of replicates nearly uniform over expression level. This transform approximates a common logarithm transform over the central working range of the assay (data not shown), and thus differences of S10-transformed data values can be interpreted as log ratios or simply "log-fold changes". A major advantage of this approach over the ordinary log-ratio is that changes in S10-transformed values have a uniform variance over the full expression scale. Visualization of the global results and detection of possible outliers among the 8 samples was facilitated by principal components analysis (PCA) of the transformed data and presentation in bivariate plots of low-order principal components.

\section{Selection of Significant Genes}

To quantify the significance of gene expression differences, a one-way, two-level ANOVA was applied comparing activated $(n=5)$ to resting $(n=3)$ T-cells. The p-value for differences between the two tissues was collected for each of the 54,675 Probe Sets. To address the multiple comparisons problem, the false discovery rate (FDR) [20] was controlled. Log fold-changes were computed as the difference between average values for the two groups. Probe sets with greater than or equal to 5 -fold change in either direction, less than or equal to $0.5 \%$ FDR (i.e. 0.005 ) and with greater than $50 \%$ of samples in at least one group having a "present call" were identified as highly significant and subjected to further analysis. Data were subsequently used for Ingenuity Pathway Analysis (IPA) [21] to model relationships among genes and proteins and to construct putative pathways. The Ingenuity Pathways Knowledge Base contains numerous modeled relationships among proteins, genes, complexes, cells, tissues, drugs, and diseases. These modeled relationships rely upon data from various primary literature sources, including peer-reviewed journal articles, review articles, and text- 
books as well as other types of content, including NCBI databases (EntrezGene, RefSeq, OMIM disease associations), Gene ontology annotations, normal gene expression for various tissues from the Genome Novartis Foundation Body Atlas, KEGG and LIGAND metabolic pathways, and cell signaling pathways.

\section{Authors' contributions}

MFE performed the lead role in all experimental work and helped to write the manuscript; SSK performed initial flow cytometric experiments; NR performed RNA extractions and amplifications; YT performed B cell activation studies; JB, JJB, and PJM performed the gene chip analysis and pathway analyses; MAS and RD assisted with experimental design and data interpretation; JPM participated in the design of experiments, coordinated the study, and participated in the writing of the manuscript. All authors have read and approved the final manuscript.

\section{Acknowledgements}

The authors would like to thank Ann Williams and Leigh Samsel of the Flow Cytometry Core Facility for their contributions to flow cytometry in this work. We also thank Neal Young, MD for his critical reading of this manuscript. This work was supported by the Intramural Research Program of the National Heart, Lung, and Blood Institute, NIH.

\section{References}

I. Solovey A, Gui L, Chang L, Enenstein J, Browne P, Hebbel RP: Identification and functional assessment of endothelial PIHI2. I Lab Clin Med 200I, I38(5):322-331.

2. Bardin N, George F, Mutin M, Brisson C, Horschowski N, Frances V, Lesaule G, Sampol J: S-endo-I, A pan-endothelial monoclonal antibody recognizing a novel human endothelial antigen. Tissue Antigens 1996, 48(5):531-539.

3. Shih IE: The Role of CDI46 (MeICAM) in Biology and Pathology. J Pathol 1999, I 89:4-II.

4. Bardin N, Anfosso F, Masse JM, Cramer E, Sabatier F, Le Bivic A, Sampol J, Dignat-George F: Identification of CDI46 as a component of the endothelial junction involved in the control of cell-cell cohesion. Blood 200I, 98(I3):3677-3684.

5. Pickl WF, Majdic O, Fischer GF, Petzelbauer P, Fae I, Waclavicek M, Stockl J, Scheinecker C, Vidicki T, Aschauer H, Johnson JP, Knapp W: MUCI 8/MCAM (CDI46), an activation antigen of human T lymphocytes. J Immunol 1997, I 58(5):2 I07-2I I5.

6. Seftalioglu A, Karakoc L: Expression of CDI46 adhesion molecules (MUCI 8 or MCAM) in the thymic environment. Acta Histochem 2000, 102:69-83.

7. Elshal MF, Khan SS, Takahashi Y, Solomon MA, McCoy JP: CDI46 (Mel-CAM), an adhesion marker of endothelial cells, is a novel marker of lymphocyte subset activation in normal peripheral blood. Blood 2005, I 06(8):2923-2924.

8. Anfosso F, Bardin N, Viviers E, Sabatier F, Sampol J, Dignat-George F: Outside in signaling pathways linked to CDI46 engagement in human endothelial cells. J Biol Chem 200I, 276(2): I564-I569.

9. Manogaran PS, Kausalya S, Pande G: Flow cytometric measurement of NK cell immunoconjugates by pulse width processing. Cytometry 1995, 19:320-325.

10. Khan SS, Solomon MA, McCoy JP: Detection of circulating endothelial cells and endothelial progenitors cells by flow cytometry. Cytometry 2005, 64B(I): I-8.

II. Fearson DT, Manders P, Wagner SD: Arrested differentiation, the self-renewing memory lymphocyte, and vaccination. Science 200I, 293:248-250.

12. Werwitzke S, Tiede A, Drescher BE, Schmidt RE, Witte T: CD28beta/CD28 expression defines functionally distinct populations of peripheral blood T Iymphocytes. Clin Exp Immunol 2003, I33(3):334-343.
13. Schultze JL, Michalak S, Seamon MJ, Dranoff G, Jung K, Daley J, Delgado JC, Gribben JG, Nadler LM: CD40-Activated human B cells: An alternative source of highly efficient antigen presenting cells to generate autologous antigen-specific $\mathbf{T}$ cells for adoptive immunotherapy. J Clin Invest 1997, I 00(I I):2757-2765.

14. Takahashi Y, McCoy JP Jr, Carvallo C, Rivera C, Igarashi T, Srinivasan $R$, Young NS, Childs RW: In vitro and in vivo evidence of PNH cell sensitivity to immune attack after nonmyeloablative allogeneic hematopoietic cell transplantation. Blood 2004, 103:1383-1390.

15. Lyons AB: Divided we stand: Tracking cell proliferation with carboxyfluorescein diacetate succinimidyl ester. Immunol Cell Biol 1999, 77:509-5।5.

16. Masinovsky B, Urdal D, Gallatin WM: IL4 acts synergistically with ILIB to promote lymphocyte adhesion to microvascular endothelium by induction of vascular cell adhesion molecule. J Immunol 1990, I 45(9):2886-2895.

17. Shimizu Y, Newman W, Gopal TV, Horgan KJ, Graber N, Beall LD, van Seventer GA, Shaw S: Four molecular pathways of $T$ cell adhesion to endothelial cells: roles of LFA-I, VCAM-I and ELAM-I and changes in pathway hierarchy under different activation conditions. J Cell Biol 1991, I I3:1203-1212.

18. Munson PJ, Barb J: Website title. [http://abs.cit.nih.gov/MSCLtool box/].

19. Munson PJ: A consistency test for determining the significance of gene expression changes on replicate samples and two convenient variance-stabilizing transformations. 200I [http:// stat-www.berkeley.edu/users/terry/zarray/Affy/GL Workshop/ genelogic200l.html]. Program and abstracts of the GeneLogic Workshop of Low Level Analysis of Affymetrix GeneChip Data, Bethesda, MD

20. Benjamini $Y$, Hochberg $Y$ : Controlling the false discovery rate: $A$ practical and powerful approach to multiple testing. J $R$ Statist Soc, Series B 1995, 57:289-300.

21. Website title [http://www.ingenuity.com/products/ pathways knowledge.html]

Publish with BioMed Central and every scientist can read your work free of charge

"BioMed Central will be the most significant development for disseminating the results of biomedical research in our lifetime. "

Sir Paul Nurse, Cancer Research UK

Your research papers will be:

- available free of charge to the entire biomedical community

- peer reviewed and published immediately upon acceptance

- cited in PubMed and archived on PubMed Central

- yours - you keep the copyright
BiolMedcentral 